\title{
The concentration of copper in the liver of African children with marasmus
}

\author{
By L. GODETTE AND P. J. WARREN \\ Department of Biochemistry, The London Hospital Medical College, \\ Turner Street, London, $E_{\mathbf{I}}$
}

(Received 10 October 1966-Accepted 28 November 1966)

\begin{abstract}
1. The concentration of copper in the liver of six African children suffering from marasmus has been compared with the values found for six children from the same area suffering from other diseases.

2. No significant difference was found in the concentration of $\mathrm{Cu}$ in the livers of children with marasmus compared with the values for the controls when the results were expressed either on a dry whole tissue basis or on a dry fat-free basis.

3. A highly significant difference was found in the concentration of $\mathrm{Cu}$ in the livers of children with marasmus when these values were compared, on a dry fat-free basis, with those found in an earlier study for children with kwashiorkor. The concentration of $\mathrm{Cu}$ in the livers of children with marasmus was twice that in the children with kwashiorkor.
\end{abstract}

Marasmus in young children is a condition widely found in tropical countries and is produced by a diet deficient in protein and calories. The effect of this type of nutrition on the copper content of the liver is not known but may be of considerable interest. Macdonald \& Warren (196I) reported a significant reduction in the concentration of $\mathrm{Cu}$ in the liver of children with kwashiorkor, compared with the values obtained for control subjects of the same age-group living in the same locality. Because of the considerable differences in lipid content of the liver between subjects with kwashiorkor and control subjects, the $\mathrm{Cu}$ concentration was measured on a dry fat-free basis, calculation indicating that there was no $\mathrm{Cu}$ present in the liver lipid.

Because of the significant reduction in $\mathrm{Cu}$ concentration in the liver of patients with kwashiorkor, it seemed desirable to discover whether this effect was unique to this condition or whether it could be demonstrated in children with marasmus, a nutritional disease developed as a result of starvation, and in which there is no fat deposition in the liver.

\section{EXPERIMENTAL}

Material. Samples of liver were obtained from six South African children aged between I year so months and 4 years, who had died from marasmus. Samples were also obtained from six children in the same age-group who had died as a result of accident or a disease other than marasmus or kwashiorkor and these served as controls. The pieces of liver were dried in a vacuum desiccator over concentrated sulphuric acid. The dried material was stored in washed paper thimbles in a desiccator. Before analysis each sample was ground to a fine powder with a glass pestle and mortar, carefully cleaned to remove any traces of $\mathrm{Cu}$; the resulting powder was stored in a glass jar with an airtight lid. 
Analytical methods. Throughout the analytical work great care was taken to avoid contamination with $\mathrm{Cu}$. All glass apparatus used was made of borosilicate glass and was cleaned by immersion in a concentrated solution of hydrochloric acid overnight followed by repeated washings with glass-distilled water. The boiling tubes used in the analytical procedure were further treated by boiling glass-distilled water in them. The glass-distilled water used for preparation of solutions and for the washing of glassware was prepared by means of an electrically heated glass-jointed still, and stored in a large polythene container. It was found to contain no detectable $\mathrm{Cu}$.

All reagents, with the exception of the concentrated nitric acid and the $50 \%$ ammonium citrate solution, were of AR quality. The nitric acid used was Electronic grade (British Drug Houses Ltd) which was found to be free of Cu contamination, and this avoided the necessity of redistilling the AR quality nitric acid under reduced pressure as this acid contains appreciable quantities of $\mathrm{Cu}$. The ammonium citrate was prepared as a $50 \%(\mathrm{w} / \mathrm{v})$ aqueous solution, and the $\mathrm{Cu}$ present in it was removed by the addition of $\mathrm{x} \%(\mathrm{w} / \mathrm{v})$ aqueous solution of sodium diethyldithiocarbamate; the yellow $\mathrm{Cu}$ complex formed was extracted with chloroform until the solvent layer remained colourless. Amyl alcohol of AR quality contains a quantity of Cu sufficient to interfere with a colorimetric determination. This was removed by double distillation in glass-jointed apparatus. The light petroleum solvent (b.p. $40-60^{\circ}$ ) was redistilled in glass-jointed apparatus. No $\mathrm{Cu}$ was detectable in the redistilled solvent. The Whatman's no. 40 filter-paper cones used in the procedure for fat extraction were first cut to size to fit a semi-micro Soxhlet apparatus and then carefully washed by refluxing them in a large Soxhlet apparatus with redistilled light petroleum solvent. They were then dried ready for use. The mean $\mathrm{Cu}$ content of four paper cones was $0.66 \pm 0.09 \mu \mathrm{g}$. This value was subtracted from all determinations in which a cone was ashed with a sample.

Fat extraction. Samples of whole dry liver powder (approximately $0.5 \mathrm{~g}$ ) were placed in filter-paper cones made from small circles of Whatman's no. $4^{\circ}$ paper previously washed in light petroleum solvent. The fat was removed from the liver samples by extraction for $12 \mathrm{~h}$ with $20 \mathrm{ml}$ light petroleum in a semi-micro Soxhlet apparatus employing a thermostatically controlled electric heating mantle. The solvent containing fat was transferred to a clean boiling-tube, the solvent removed with the aid of heat and reduced pressure, and the fat content of the sample determined by weight.

Preparation of samples for the determination of $\mathrm{Cu}$. Small samples of dried whole liver or fat-free liver powder in paper cones were placed in clean boiling-tubes by means of a clean stainless steel spatula. The contents of the tubes were dried to constant weight at $110^{\circ}$.

The organic material was destroyed and the samples were oxidized by a modification of the method described by Eden \& Green (1940). To each boiling-tube containing liver powder was added I $\mathrm{ml}$ of concentrated sulphuric acid, $2 \mathrm{ml}$ of $60 \%$ perchloric acid, and then $2 \mathrm{ml}$ of Electronic grade nitric acid. The initial stage of gentle heating described by Eden \& Green was omitted but was replaced by warming the boilingtubes, containing the liver sample and acid mixture, under a row of infrared lamps 
until all the organic material had dissolved in the acid mixture, producing a deep red or yellow solution with no frothing. The digested samples were transferred to an electrically heated Kjeldahl-type digestion rack and then heated more strongly until the solution was boiling gently. This process was completed when approximately $\mathrm{I} \mathrm{ml}$ of a clear colourless liquid remained in each tube.

$\mathrm{Cu}$ determination. The $\mathrm{Cu}$ content of each tissue sample was determined with sodium diethyldithiocarbamate (Eden \& Green, 1940). The yellow complex formed in the presence of $\mathrm{Cu}$ was extracted into amyl alcohol and measured spectrophotometrically at $435 \mathrm{~nm}$.

Table I. Concentration of copper in the livers of African children who had died from marasmus or from other causes

\begin{tabular}{|c|c|c|c|c|c|c|c|}
\hline \multirow{2}{*}{\multicolumn{4}{|c|}{ Subject }} & \multirow{3}{*}{$\begin{array}{c}\text { Fat } \\
\text { (g/Ioo g } \\
\text { tissue) }\end{array}$} & \multicolumn{3}{|c|}{$\mathrm{Cu}(\mu \mathrm{g} / \mathrm{g} \text { dry tissue })^{*}$} \\
\hline & & & & & \multirow{2}{*}{$\begin{array}{l}\text { Fat- } \\
\text { free } \\
\text { tissue }\end{array}$} & \multirow{2}{*}{$\begin{array}{l}\text { Whole } \\
\text { tissue }\end{array}$} & \multirow{2}{*}{$\begin{array}{l}\text { Whole } \\
\text { tissue } \\
\text { (cal- } \\
\text { culated) }\end{array}$} \\
\hline Code & Age & Sex & Cause of death & & & & \\
\hline Coroner 20 & I year 6 months & $\delta$ & Street accident & 10.0 & $3^{8 \cdot 1}$ & $30 \cdot 8$ & $34 \cdot 3$ \\
\hline 2557 & 2 years 6 months & q & Septicaemia & $25 \cdot 6$ & $34 \cdot 3$ & $32 \cdot 3$ & 25.5 \\
\hline 2559 & I year 2 months & $\hat{\jmath}$ & Gastroenteritis & 10.5 & $27 \cdot 3$ & $24 \cdot 6$ & $24 \cdot 5$ \\
\hline 2555 & Io months & $\hat{o}$ & Gastroenteritis & $22 \cdot 2$ & $22 \cdot 5$ & $12 \cdot 1$ & I 7.5 \\
\hline $255^{6}$ & I I months & 웅 & Gastroenteritis & $19 \cdot 7$ & 19.9 & $15 * 4$ & $15-9$ \\
\hline \multirow[t]{2}{*}{2362} & I year 9 months & $\partial$ & Peritonitis & $12 \cdot 6$ & $33^{\prime} I$ & 一 & $29 \cdot 1$ \\
\hline & $\begin{array}{l}\text { Mean value } \\
\text { Standard deviation }\end{array}$ & & & $\begin{array}{r}16.8 \\
\pm 6.0\end{array}$ & $\begin{array}{r}29.2 \\
\pm 6 \cdot 9\end{array}$ & $\begin{array}{r}23 \cdot 0 \\
\pm 8 \cdot 4\end{array}$ & $\begin{array}{r}24 \cdot 4 \\
\pm 7 \cdot 0\end{array}$ \\
\hline 2565 & I year ro months & $\delta$ & Marasmus & $17 \cdot 9$ & $33 \cdot 4$ & - & $27 \cdot 4$ \\
\hline I $39 / 6 \mathrm{I}$ & 4 years & $\delta$ & Marasmus & - & $39 \cdot I$ & - & - \\
\hline $308 / 61$ & 4 years & $\overrightarrow{3}$ & Marasmus & $17 \cdot 2$ & $24 \cdot 6$ & - & $20 \cdot 4$ \\
\hline $\mathrm{N} 232$ & 3 years & 오 & Marasmus & II'I & $34^{\circ} 9$ & $3 I \cdot 8$ & $31 \cdot 0$ \\
\hline $\mathrm{N}_{3}{ }_{7}$ & 3 years & ठే & Marasmus & $26 \cdot 0$ & $25^{\circ} 0$ & 一 & $18 \cdot 5$ \\
\hline \multirow[t]{2}{*}{$\mathrm{N} 292$} & 4 years & q & Marasmus & $20 \cdot 1$ & $53 \cdot 8$ & $43^{2} 2$ & $43^{\circ} \circ$ \\
\hline & $\begin{array}{l}\text { Mean value } \\
\text { Standard deviation }\end{array}$ & & & $\begin{array}{r}18.5 \\
\pm 6.2\end{array}$ & $\begin{array}{r}35^{\cdot} \mathbf{I} \\
\pm I I \cdot I\end{array}$ & - & $\begin{array}{r}28 \cdot 0 \\
\pm 10 \cdot 2\end{array}$ \\
\hline
\end{tabular}

\section{RESULTS}

Liver. The concentration of $\mathrm{Cu}$ in the livers of African children with marasmus and those children from the same region who died from causes other than marasmus or kwashiorkor are shown in Table $\mathbf{I}$. Comparison of these values on a dry fat-free $(P<0.3)$ or a dry whole tissue basis $(P<0.5)$ showed no significant difference. In Table 2 a comparison is made of the $\mathrm{Cu}$ concentration of the liver in children with marasmus and with kwashiorkor, and in children who died accidentally or from conditions which were not forms of malnutrition and who were used as controls. Comparison of the controls used in the present work (controls $M$ ) with those used in the previous study on kwashiorkor (controls K) (Macdonald \& Warren, r96r) showed no significant differences when the $\mathrm{Cu}$ concentration was expressed either on a whole 
dry $(P<0.4)$ or on a fat-free dry $(P<0.2)$ liver basis. However, comparison of the $\mathrm{Cu}$ levels in marasmic subjects with those in the kwashiorkor group showed a very significant difference, when expressed on a fat-free dry liver basis $(P<0.001)$.

Table 2. Comparison of the copper concentration and fat content in the liver of African children who had died from marasmus or kwashiorkor or other causes

\begin{tabular}{|c|c|c|c|c|}
\hline & $\begin{array}{c}\text { Controls } M \\
\text { (no marasmus } \\
\text { or } \\
\text { kwashiorkor } \\
\text { present) }\end{array}$ & Marasmus & Kwashiorkor* & $\begin{array}{c}\text { Controls } \mathrm{K}^{*} \\
\text { (no marasmus } \\
\text { or } \\
\text { kwashiorkor } \\
\text { present) }\end{array}$ \\
\hline \multicolumn{5}{|c|}{$\mathrm{Cu}$ content of liver ( $\mu \mathrm{g} / \mathrm{g}$ fat-free dry tissue) } \\
\hline $\begin{array}{l}\text { Mean value } \\
\text { Standard deviation } \\
\text { No. of cases }\end{array}$ & $\begin{array}{r}29 \cdot 2 \\
\pm 6 \cdot 9 \\
6\end{array}$ & $\begin{array}{c}35 \cdot I \\
\pm I I \cdot I \\
6\end{array}$ & $\begin{array}{r}17 \cdot 3 \\
\pm 3 \cdot 9 \\
7\end{array}$ & $\begin{array}{c}24 \cdot 4 \\
\pm 7 \cdot 3 \\
9\end{array}$ \\
\hline \multicolumn{5}{|c|}{ Fat content of liver ( $\mathrm{g} / \mathrm{r} 00 \mathrm{~g}$ whole tissue) } \\
\hline $\begin{array}{l}\text { Mean value } \\
\text { Standard deviation } \\
\text { No. of cases }\end{array}$ & $\begin{array}{l}16 \cdot 8 \\
\pm 6 \\
6\end{array}$ & $\begin{array}{l}18 \cdot 5 \\
\pm 6 \cdot 2 \\
6\end{array}$ & $\begin{array}{r}57 \cdot 7 \\
\pm 15 \cdot 3 \\
7\end{array}$ & $\begin{array}{r}18 \cdot 1 \\
\pm 17 \cdot 9 \\
9\end{array}$ \\
\hline
\end{tabular}

\section{DISCUSSION}

The problem of defining the two main types of infantile malnutrition involving protein deficiency has recently been discussed (McCance \& Widdowson, I966; Platt, r966). McCance \& Widdowson consider that these two types, marasmus and kwashiorkor, are both the result of an inadequate intake of protein. The syndrome of kwashiorkor develops when the calorie intake in the child is relatively adequate, that of marasmus when the child is starved of both protein and calories. The similarity between some of the clinical features of kwashiorkor and those of $\mathrm{Cu}$ deficiency in sheep has been discussed, and the presence of a significantly reduced $\mathrm{Cu}$ concentration in the liver of kwashiorkor subjects has been reported (Macdonald \& Warren, 196r). Comparison of the liver $\mathrm{Cu}$ levels found in marasmic children in this work with the values reported for kwashiorkor show a very significant difference when expressed on a dry fat-free basis.

The values for the liver of marasmic children were very similar to those for the control group living in the same locality who were not severely malnourished. This suggests that the low $\mathrm{Cu}$ concentration found in the liver of children with kwashiorkor is not simply due to a state of malnutrition produced by a reduced intake of food. The staple diet of children living in this region is maize, which has a low $\mathrm{Cu}$ content (0.6-0.8 ppm, Albritton, 1954). Since the daily food intake of a child with marasmus is probably considerably less than that of a normal child, the inference may be drawn that the total daily $\mathrm{Cu}$ intake is less than normal. If this is so the differences between the concentrations of $\mathrm{Cu}$ found in children with marasmus and in children with kwashiorkor could not be explained on the basis of an increased food intake by the children with marasmus. 
We are most grateful to Dr I. Macdonald of Guys Hospital Medical School for obtaining the liver samples, and to Professor F. L. Warren in whose department this work was carried out.

\section{REFERENCES}

Albritton, E. C. (editor) (1954). Standard Values in Nutrition and Metabolism. Philadelphia: W. B. Saunders.

Eden, A. \& Green, H. H. (1940). Biochem. F. 34, 1202.

Macdonald, I. \& Warren, P. J. (I961). Br. F. Nutr. 15, 593.

McCance, R. A. \& Widdowson, E. M. (1966). Lancet ii, $5_{5} 8$.

Platt, B. S. (1966). Lancet ii, 283. 